\title{
5. China's High Rates of Investment and Path Towards Internal Rebalancing
}

Owen Freestone and Dougal Horton ${ }^{1}$

\section{Introduction}

China's investment share of GDP remains at an unusually high rate, even when compared with other East Asian economies at a similar stage of development. This chapter documents the likely causes of China's high rates of investment and how the authorities' planned market-oriented reforms might play a role in reducing investment and boosting household consumption in the future. Using more-advanced Asian economies' experiences as a guide, our analysis suggests that a 10 percentage point reduction in China's investment share of GDP (and a commensurate rise in household consumption) could take place over a 10-year period, and could in theory occur without any major disruptions to economic growth and capital accumulation. Having established the plausibility of this scenario, we introduce this shock into a global computable general equilibrium (CGE) model with China's economy represented along with an offsetting rise in productivity, imagining that the Chinese authorities' planned reforms are successful in boosting the efficiency of capital across the economy. We do this simply to demonstrate the effects of such a development. We find that this shock leads to a shift in household spending towards services and away from manufactured goods, and a small decrease in exports while at the same time a small increase in imports, which reduces China's trade surplus, consistent with the shift from investment towards consumption.

This chapter is divided into two sections. The first section familiarises readers with the evolution of China's macro-economy, shows how its structure has changed through time compared with other economies at similar stages of their development, and discusses some of the reasons put forward for China's very high rates of investment.

1 The authors are, or were, from the International Economy Division of the Australian Treasury. The CGE modelling used in this chapter was developed by Liangyue Cao, Qun Shi, Cedric Hodges and Wallace Stark from the Macroeconomic Modelling and Policy Division. This chapter has benefited from comments and suggestions provided by Sam Hill, Bonnie Li, Mark Frost and Richard Wood. The views in this chapter are those of the authors and not necessarily those of the Australian Treasury. 
Building on the findings of the first section, the second section explores the scenario of a gradual 10 percentage point reduction in China's investment share of GDP over a 10-year period. Having established the overall reasonableness of such a transition, results of a similar shock in a version ${ }^{2}$ of the Global Trade and Environment Model (GTEM) (Pant 2007) are discussed, including how the authorities' planned productivity-boosting reforms might help offset the impact of lower investment on China's real GDP.

\section{China's economic and industrial transformation since 1978}

\section{Overview of China's rise}

Supported by vast labour endowments and the rapid accumulation of capital goods, the structural reform and opening-up processes have steered China's transition from an agrarian economy to one led by modern industry and services.

Similar to other East Asian economies before it, China has exploited to great effect the advantages of 'backwardness'. As a late developer, China has been able to import and quickly adapt the technologies and production techniques of advanced economies, without bearing the delays and costs involved in research and development.

Consequently, China's share of world output doubled in just over a decade from the beginning of reform in 1978. Over the past three decades, China's share of world output has increased eightfold and on most estimates it could overtake the United States as the world's largest economy by 2020.

This remarkable transformation has, however, coincided with substantial structural imbalances, and economic and social challenges. Chinese growth is heavily reliant on unsustainably high investment rates, encouraged by distortionary policies that divert resources away from households to the corporate sector to encourage the accumulation of physical capital stock. ${ }^{3}$ These settings have led to over-leveraging and inefficient investment in some sectors, putting financial stability and future growth at risk. It has also come with high environmental costs, which may limit the rate of future industrial expansion, at least in some regions of China.

2 This is a version of GTEM with some modifications made by the Australian Treasury.

3 Hereinafter, the term 'capital stock' will refer to 'physical capital stock' unless otherwise stated. 
Over the next decade, the key challenge facing the Chinese authorities will be to support the economy's transition towards a new pattern of growth. Only through shifting towards an economy driven by private, rather than state, investment decisions will China be able to make continued productivity gains and progress towards the higher-income East Asian economies. With China's demographics expected to become an increasing drag on growth in coming decades, continued productivity gains will be all the more crucial.

Of course, China is not the first economy to face such challenges. This section examines China's current economic structure, comparing China with other East Asian economies as they transitioned along their own development paths. ${ }^{4}$ We also include the United States as a benchmark in our chart analysis, to show how China's transition compares with another economy that was large enough to affect the overall global economy during its development.

\section{Falling household consumption share of GDP}

The rapid expansion of China's productive capacity-including through massive investment in infrastructure - has supported (and been supported by) the migration of hundreds of millions of rural workers to higher-paying jobs in the urban manufacturing sector. These higher wages have flowed to the broader economy, underwriting a sustained increase in average household incomes and consumption. Since 1978, wages have increased at an average annual rate of 14 per cent, and household consumption by 15 per cent. Nonetheless, investment has grown at a much faster rate, pushing down the household consumption share of GDP to a historically low 35 per cent (Figure 5.1).

As indicated in Figure 5.1, the household consumption share of GDP typically declines in the first stages of economic development as the economy moves from a subsistence-like state in which most output is consumed. As the economy develops, investment accelerates. Surplus labour ensures that, although household incomes grow, the share of national income held by the household sector remains relatively low. As a result, investment grows faster relative to household consumption so that the consumption share of GDP

4 There are three main inputs into the production process: physical capital (factories, manufacturing equipment); human capital (the skills, knowledge and experience of the workforce); and natural capital (the stock of natural resources). The efficiency with which these inputs are used to produce an economy's output can indicate the level of economic development. In practice, however, calculating the productivity of capital can be difficult, primarily due to the difficulty in estimating the contribution from both human and natural capital. Instead, this chapter uses real GDP per capita (adjusted for purchasing power parity) to measure the level of development. GDP per capita is readily available for most economies and is an indicator of the relative productivity with which different economies use their resources. 
falls. For example, the household consumption share of the Korean economy experienced a sharp fall, from more than 80 per cent in the early 1960s (Korea's 'take-off' point) to 54 per cent in 2012.

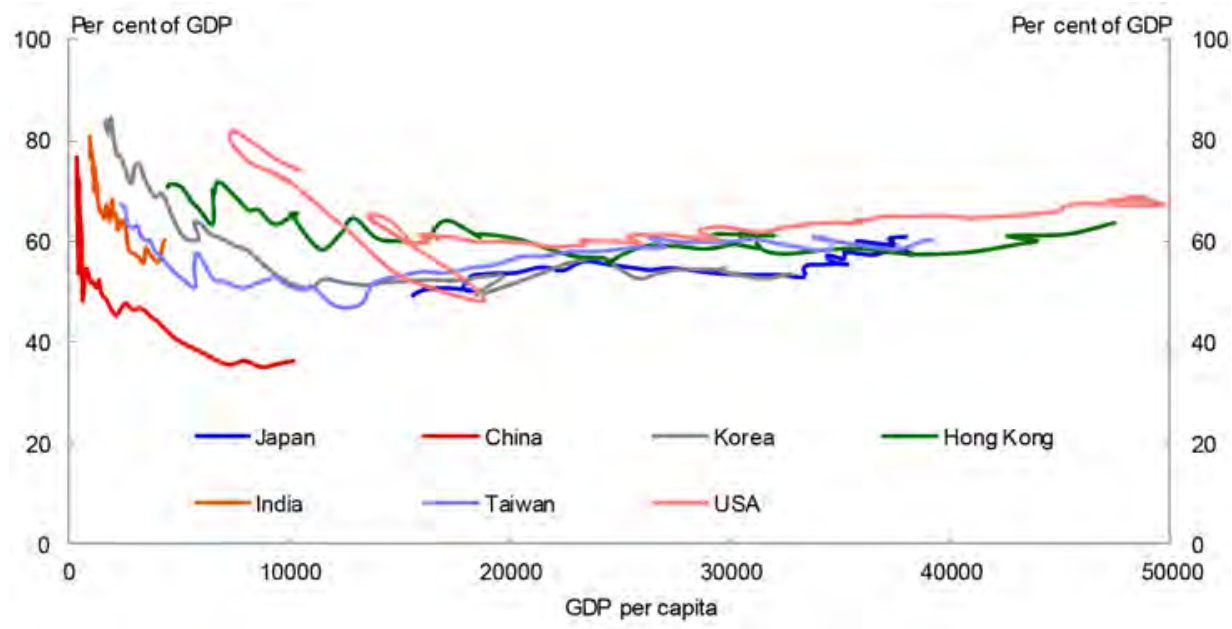

Figure 5.1 Household Consumption

Sources: World Bank (2012); CEIC Asia; US Bureau of Economic Analysis; Maddison (2010); and Australian Treasury.

Note: GDP per capita adjusted for purchasing power parity (PPP) (2011 prices).

Figure 5.1 also shows, however, that the household consumption share of Chinese GDP has fallen further and faster than that of its East Asian peers. In Korea, the share of GDP accounted for by household consumption reached a low of around 50 per cent in 1988 when at a similar stage of development as China is at today.

The low and declining share of Chinese household consumption over the past three decades has been predominantly driven by the household sector's declining share of national income (Aziz and Cui 2007). This decline has occurred across all main household income sources - wages, property income and government transfers - and reflects the traditional heavy bias in China's economic model in favour of the corporate sector. Features of this model include a very limited social safety net (especially for migrant workers), artificially low prices on factor inputs and so-called 'financial repression' (limited savings vehicles for households as an alternative to the state-regulated low returns on bank deposits and the implicit transfer of those funds to the corporate sector 
through a subsidised cost of capital). ${ }^{5}$ Along with low wages stemming from surplus labour, these features have meant that the share of national income held by households remains relatively low, having fallen steadily since the mid 1990s. At the same time, these features have encouraged high rates of household saving, reinforcing China's low share of household consumption in GDP.

\section{Industrialisation and export-led growth}

Following in the footsteps of many other East Asian economies, China's rapid economic growth and rise in living standards since the modern reform period began have been driven by the accumulation of capital goods and the state-supported development of an internationally competitive manufacturing sector. As Rodrick (2013) notes, manufacturing industries can propel an economy forward, even in the presence of bad governance, bad policies and a disadvantageous context - not to say that China has been hampered by these factors.

As with other East Asian economies, China's export sector had a central role in underpinning China's rise. This partly reflects the positive spillover effects typically associated with export-led growth, especially in the transmission of new technologies and business practices to other sectors of the Chinese economy, which supported substantial economy-wide productivity gains. Equally, the large-scale migration of surplus rural labour to urban areas gave manufacturers access to a deep pool of low-cost labour, reinforcing the logic of this model of growth.

Over the 1970s, the manufacturing sector rose quickly as a share of the Chinese economy as easy gains were made through capital accumulation, technology transfer and the utilisation of cheap surplus labour. Between 1978 and 1980 manufacturing accounted for around 40 per cent of Chinese output. As incomes have risen and China has slowly moved towards a consumer and services-based economy, this share has eased to around 30 per cent today, comparable with Taiwan and Korea at similar stages of development.

Over the past two decades, this investment in productive capacity and other capital goods has contributed almost half of China's economic growth. Investment (gross fixed capital formation) averaged approximately 30 per cent of GDP in the 1980s, before steadily increasing to reach 47 per cent in 2012.

5 Aziz and Cui (2007) found that financial repression was a major reason for the low and declining household wage and investment income shares of national income. Borrowing constraints limiting firms' access to bank financing for working capital acted as a tax on labour input, discouraging the use of labour. 
As shown in Figure 5.2, a sharp rise in the investment-to-GDP ratio is characteristic of a developing economy, reflecting the high returns on new capital during the earlier stages of development. At 47 per cent, however, the investment share of Chinese GDP is well above the peaks experienced in other East Asian economies. For example, the investment-to-GDP ratio in Japan peaked at 36 per cent in 1973 and in South Korea at 39 per cent in 1991.

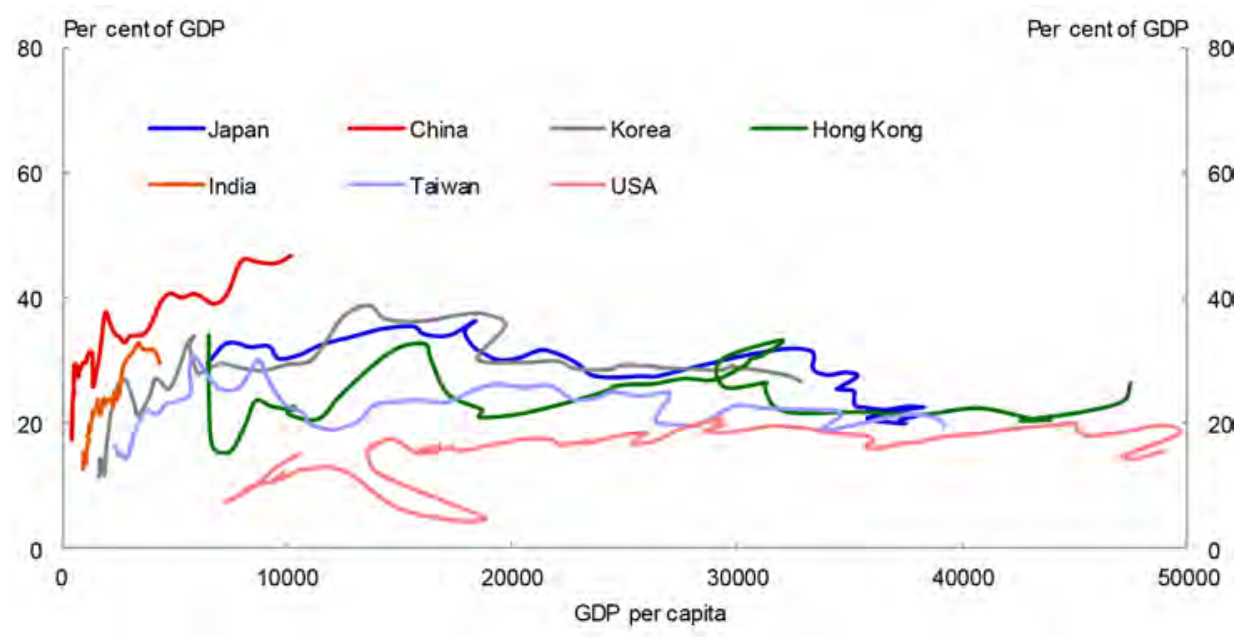

Figure 5.2 Investment

Sources: World Bank; CEIC Asia; US Bureau of Economic Analysis; Maddison (2010); and Australian Treasury.

Notes: GDP per capita adjusted for purchasing power parity (2011 prices). 'Investment' is defined as gross fixed capital formation.

China's capital stock is estimated to have grown at an average annual rate of 10 per cent in real terms over the past 30 years (Berlemann and Wesselhoft 2012). Despite this expansion, China's capital stock per worker remains a small fraction of that of advanced economies (Figure 5.3). Based on estimates from Berlemann and Wesselhoft (2012), China's capital stock per worker is only 5 per cent of that of the United States (in real terms at market exchange rates). Even after adjusting for differences in purchasing power, this figure is only 13 per 
cent. In comparison, Korea's capital stock per worker (in PPP terms) was around 30 per cent of the United States' in 1988 when at a similar stage of development to China today. ${ }^{6}$

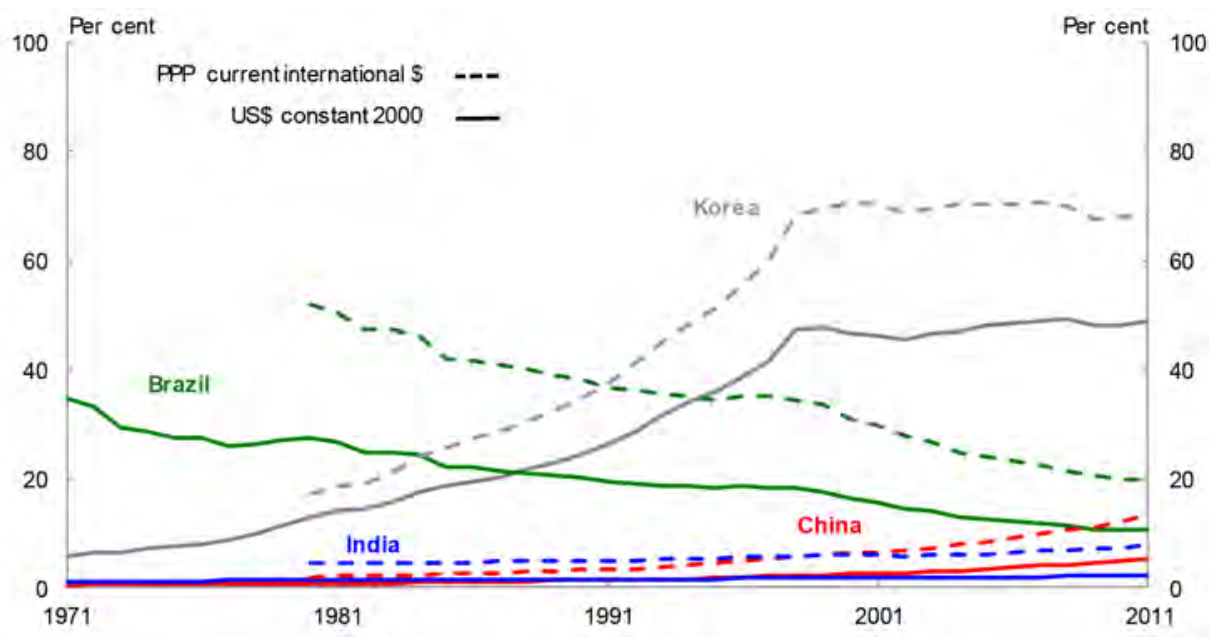

Figure 5.3 Physical Capital Stock Per Worker as Percentage of the United States

Sources: World Bank; Berlemann and Wesselhoft (2012); The Conference Board Total Economy Database ${ }^{\mathrm{TM}}$; and Australian Treasury.

Notes: GDP per capita adjusted for purchasing power parity (2011 prices). 'Worker' is defined as those persons who are employed as defined in The Conference Board Total Economy Database ${ }^{\mathrm{TM}}$.

\section{State incentives support high national saving and investment}

China's high investment rate has been supported by an even higher rate of domestic saving, which is elevated by international standards and has grown considerably since the modern reform period commenced. The national saving rate rose from around the 30 per cent range in the early 1980s to a peak of 53 per cent in 2008, before easing to 51 per cent in 2012. China's saving rate has consistently surpassed its investment rate for most of that period (Figure 5.4), and far exceeds that of its East Asian peers (Figure 5.5).

6 An issue worth noting when comparing capital stock per worker between economies at equivalent stages of development is that capital stock per worker is itself a measure of economic development; however, the efficiency with which physical capital is used by the workforce - that is, the productivity of the capital stock - would have implications for differences in capital stock per worker, and can be affected by the quality and quantity of an economy's stock of human and natural capital, and broader access to production technologies. Moreover, data for GDP are typically more reliable than those for capital stock, with capital stock data quite sensitive to depreciation rate assumptions. Therefore, we have used GDP per capita to measure stage of development. See Footnote 4 for further discussion regarding our choice of GDP per capita as the indicator of stage of development. 


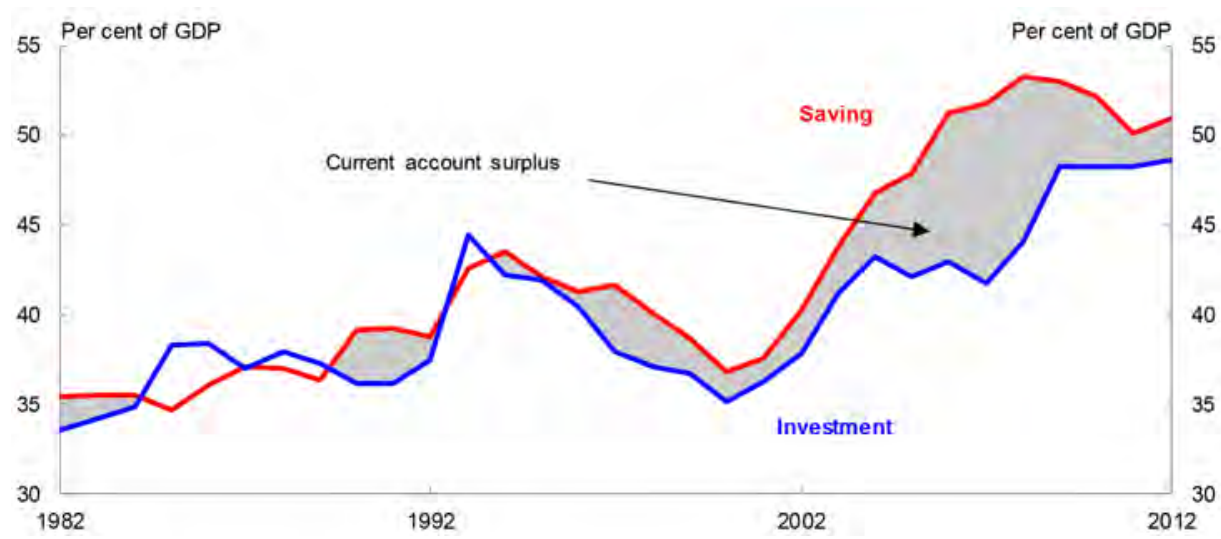

Figure 5.4 China's Saving and Investment Rates

Sources: IMF October 2013 WEO; CEIC China; and Australian Treasury.

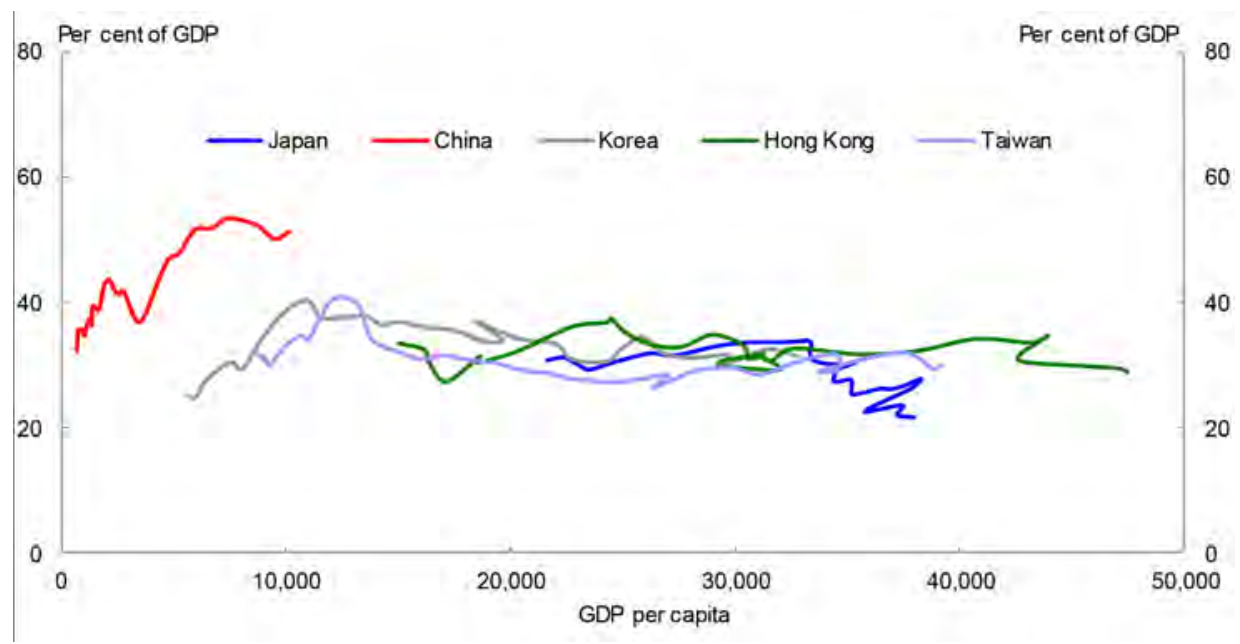

Figure 5.5 Saving

Source: IMF October 2013 WEO; Maddison (2010); and Australian Treasury.

Note: GDP per capita adjusted for purchasing power parity (2011 prices).

The household sector has accounted for around half of China's national saving since 1992. This has been driven over the past 30 years by a large and growing working-age population with a greater capacity to save compared with their young and elderly dependants (Kong et al. 2012). Incomplete domestic financial markets and limited access to foreign financial markets also encourage higher saving rates, as does the paucity of social services such as education, health care and social insurance. 
Corporate saving, however, has also made a large contribution to the increase in national saving over this period, accounting for around 43 per cent of the increase. In particular, a lax dividend policy has allowed state-owned enterprises (SOEs) to retain and then reinvest most of their profits, rather than distribute to households via dividend payouts to the state. Financial underdevelopment has also made it difficult for the private sector, especially small businesses, to access intermediated financing, inducing higher saving rates in that sector.

The build-up in corporate saving has also been supported by favourable government policies designed to boost the development of the industrial sector-a key component of China's development model. For instance, domestic costs of key factor inputs such as land, water, energy and fuel have historically been relatively low by international standards, partly reflecting government policies that have regulated below-market prices (World Bank 2012). ${ }^{7}$

Most importantly, government policy settings have ensured the Chinese household and private sectors effectively subsidise the channelling of China's vast stock of savings into corporate investment at below-market prices. Market signals have only a limited role in China's underdeveloped and largely statecontrolled banking system, which is characterised by the use of quantitative controls to manage the supply and allocation of credit and the regulation of benchmark deposit and lending interest rates (although the floor on the lending rate was removed for most bank loans in 2013). This regulated system both guarantees Chinese banks a minimum interest rate margin and allows banks to provide cheap loans to the corporate sector, especially SOEs.

After adjusting for inflation, returns on bank deposits have been negative for prolonged periods, with the real one-year benchmark deposit rate averaging -0.3 per cent over the past decade. The real one-year benchmark lending rate has averaged just 2.9 per cent over the same period.

Aided by relatively tight capital controls, these policy settings have secured a cheap and stable domestic funding source for China's large corporations and SOEs since the early 2000s, promoting high rates of economic growth through capital accumulation. ${ }^{8}$

7 The total value of China's factor market distortions could total almost 10 per cent of GDP (Ahuja et al. 2012).

8 Other factors have also contributed. Private home ownership, permitted from the late 1990s, has led to a surge in property investment. Moreover, central authorities implicitly encourage local government officials to generate high investment rates with an incentive structure that rewards rapid economic growth. 
The relatively healthy headline rate of return on capital remains a powerful incentive for investment in China. Putting government subsidies to one side, the return on capital is generally an indicator of the productivity (or efficiency) of investment. The higher the return, the greater is the demand for new capital goods, consistent with the profitable opportunities for further investment.

Figure 5.6 shows two estimates for historical returns in China, suggesting a decline of approximately 10 percentage points since the early 1990s. Despite this moderation, the return on capital remains high in China relative to other East Asian economies. HSBC estimates that the return on capital in Singapore, Korea and Hong Kong could be less than 6 per cent, in part reflecting their much more advanced stages of development.

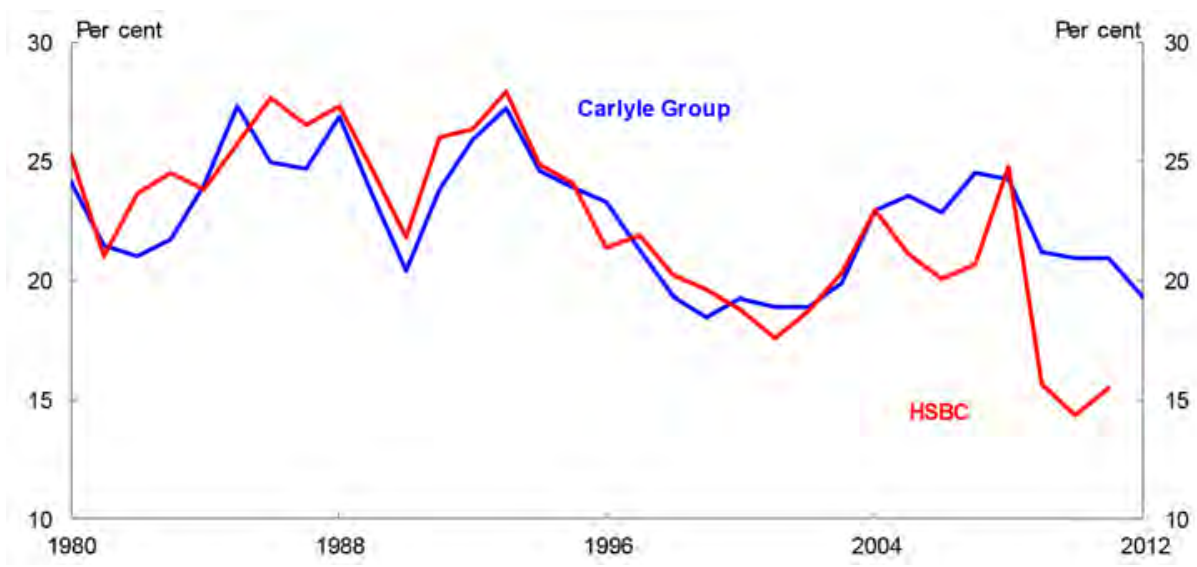

Figure 5.6 Return on Capital

Sources: HSBC Global Research (2013); Carlyle Group (2013).

A declining rate of return is consistent with a rising capital-to-output ratio, indicating an increase in the amount of capital required to generate one unit of output. As indicated in Figure 5.7, although China's capital-to-output ratio is rising, it remains low relative to more advanced economies. 


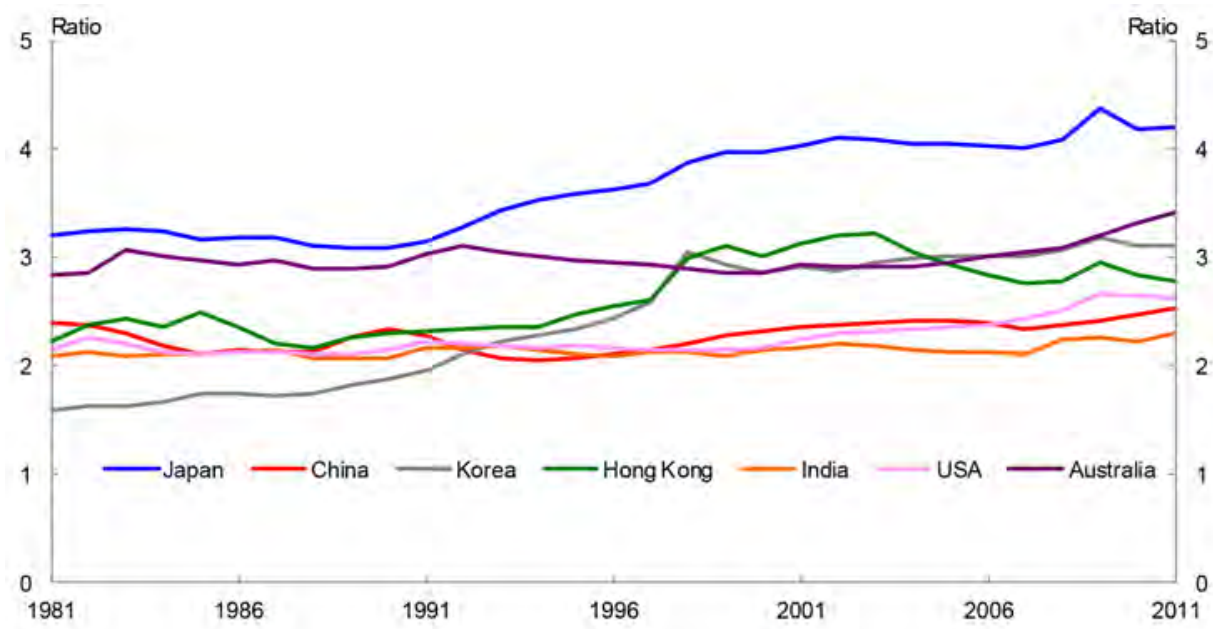

Figure 5.7 Capital-to-Output Ratio

Source: World Bank; Berlemann and Wesselhoft (2012); and Australian Treasury.

Note: Capital and output adjusted for purchasing power parity (2011 prices).

To some extent, declining returns and a rising capital-to-output ratio are natural outcomes as an economy modernises. As an economy shifts away from labour-intensive agriculture towards more capital-intensive modern industries, capital requirements per unit of output naturally increase. It is also consistent with rising labour costs associated with diminishing surplus labour. Moreover, the most recent decline in returns in China could be partly explained by the burst of investment related to the Global Financial Crisis (GFC) in longer-dated infrastructure projects, which tend to weigh on returns in the short term. Over the longer term, these projects can increase the overall efficiency and productive capacity of the economy, generating significant returns and an ongoing rise in living standards (although, some of the most poorly targeted investment during the GFC may never yield an economic return).

China is still in the catch-up phase of capital formation, as indicated by a low capital stock per worker (see Figure 5.3). Driven by the urbanisation process, demand for infrastructure remains substantial, particularly in urban housing, transport, water and energy, and education and health services. And as factor costs rise, China will need to shift up the value chain to remain globally competitive, requiring further upgrading of China's manufacturing and broader productive capabilities (Coates et al. 2012). As such, the relatively high returns available to investors will remain an incentive for continued investment in China, albeit to a lesser extent than in the past. 


\section{Diminishing returns to investment}

Using the headline return as a measure of the efficiency of investment, however, assumes that inputs are priced according to market forces. The relatively high returns still available in China are probably distorted by the below-market pricing of factor inputs and other policies favouring the corporate sector, thus concealing the growing inefficiency of investment in some sectors of the Chinese economy.

For example, Lee et al. (2013) found that investment in inland provinces is progressively becoming less efficient. Reflecting this, private consumption in these regions only benefited in the short run through the direct effect of higher wages and other income paid out during the investment phase. In the longer run, the impact on private consumption was found to be small, as the poor quality of the project meant the capital stock was not sustainably increased by the investment.

Moreover, despite higher investment and rapid credit expansion, Chinese economic growth is easing, in part indicating diminishing returns to physical capital accumulation and the misallocation of resources (Nabar and N'Diaye 2013).

The decline in the return on capital and growing evidence of capital misallocation have contributed to concerns that China has invested in substantial capacity far ahead of demand, and that the productivity of investment is falling too quickly. According to this argument, although new investment generates an initial burst of economic growth, much of it is in unproductive or underutilised projects, and is unlikely to make a further contribution to GDP (unless this spare capacity becomes utilised in the future). In effect, this represents a reduction in the efficiency of capital. This can be seen, for example, in the build-up of overcapacity in parts of China's industrial sector, such as steel and shipbuilding, and in underused motorways. With sustained urbanisation and economic growth, however, it is important to remember that initially underutilised infrastructure can become economically useful over time.

China's falling capacity utilisation rate could provide evidence of overcapacity and a decline in the efficiency of investment. In November 2013, the National Development and Reform Commission reported that China's industrial capacity utilisation rate fell to 78 per cent in the first half of 2013, the lowest rate since the last quarter of 2009. ${ }^{9}$ Some Chinese industries are more affected by overcapacity than others, particularly those related to the construction sector. For example, as of the end of 2012 the capacity utilisation rate for the shipbuilding industry was 75 per cent, and in the iron and steel industry the rate was only 72 per cent.

9 The IMF estimates that China's capacity utilisation rate declined from just less than 80 per cent before the GFC to 60 per cent in 2012 (IMF 2012). 
The limited role of market signals in China's state-controlled banking system and low cost of capital have been key drivers of these developments. While the banking sector remains immensely profitable, the suppression of market forces has hampered the development of an efficient commercially oriented banking system with sufficient risk-management capabilities. ${ }^{10}$ This strategy has encouraged over-leveraging ${ }^{11}$ and, by diverting financial resources away from the more dynamic private sector to less-efficient SOEs, has contributed to the misallocation of capital.

\section{How might China's transition take shape?}

China's economic transition-towards household consumption, services and the more efficient use of factors of production - will, at least to some extent, occur even without substantial new economic reforms. The economic pressures from an exhaustion of surplus labour and the associated wage increases will boost the household sector's share of national income, and reduce the incentive for the corporate sector to invest (Huang et al. 2013). And, as noted by Garnaut et al. (2013) in the 2013 edition of the China Update, labour-market shifts have already been driving structural change in China since the mid 2000s.

This does not, however, discount the importance of government policy, as argued above. The combined effect of a regulated cost of capital (and other key inputs), a financial system consisting mainly of state-owned banks, a tightly controlled capital account and a system of government that has incentivised provincial leaders to prioritise economic growth above all else has undoubtedly contributed to some overinvestment. And with increasing evidence of poor investments and a falling efficiency of capital, Chinese authorities have come to accept that a new wave of market-oriented reforms is needed to maintain strong economic growth and reinforce the economy's transition towards a more services and consumer-based economy.

The market-oriented reform ambitions outlined at the Chinese Communist Party's Third Plenum in November 2013 provide the latest indication of the authorities' recognition of the need for fresh economic and structural reforms. At its core, this agenda recognises that China's continued economic development will require a more efficient allocation of resources, especially capital. Only through more market-based methods of allocating capital and other factors of production will China be able to achieve its objective of strong and sustained economic growth, and higher incomes and private consumption.

10 The development of China's shadow banking industry has occurred partly as a way of circumventing the tightly regulated conventional banking system.

11 China's total debt-to-GDP ratio (including household, corporate and all levels of government debt) is estimated at more than 200 per cent-high for an emerging economy. 
Following the example set by other East Asian economies since the 1970s, China's transition will be characterised by a falling investment share of GDP. In China, this is expected to occur as state-led investment progressively gives way to greater private-led economic activity, supported by ongoing marketoriented reforms. As wages rise, the economy's resources will shift more towards the production of goods and services for domestic household consumption. Labour scarcity and the accompanying rise in wages will continue to drive Chinese manufacturing further up the production value chain towards more technologically sophisticated goods with a higher valued-added contribution from domestic sources, including from the services sector (Garnaut et al. 2013).

While there is clearly still far to go, a range of indicators suggests this transition is already under way. The household consumption and investmentto-GDP ratios appear to be stabilising after their natural transition paths were disrupted by the burst of GFC-related investment stimulus measures (see Figures 5.1 and 5.2). Last year, the services sector accounted for 46 per cent of Chinese GDP-larger than the share from the industrial sector (44 per cent). This was the first time since at least 1952 that the services sector has accounted for the single largest share of the Chinese economy. China's national saving rate has declined from a high of 53 per cent in 2008 to 51 per cent in 2012, and the current account surplus has narrowed from 10 per cent of GDP in 2007 to 2.3 per cent in 2012 (albeit driven in part by a surge in imports of raw materials and other inputs into China's GFC investment spree).

This section examines the potential transition path China might take in the coming decade. It will not attempt to add to the literature on the necessary reforms or prospects for implementation. Rather, we assume that over the next decade, through a combination of natural forces and appropriate economic reforms, China will shift further towards a more market-based economy. In our scenario, these reforms contribute to a gradual decline in China's investmentto-GDP ratio, in part through a reduction in the implicit investment subsidy that is currently provided by the household sector to the corporate sector discussed above.

Also, we do not initially attempt to estimate the 'reform dividend' - that is, the boost in private investment by non-SOEs that might result from better access to capital and a generally more conducive operating environment for private enterprise. Instead, in the final subsection of the chapter, we explore the idea of an offsetting (in terms of the net effect on real GDP) increase in capital efficiency, which is probably a more widely accepted way of thinking about China's reform dividend. 


\section{Declining investment-to-GDP ratio}

Lee et al. (2012) used dynamic panel data models for 36 economies from 1955 to 2009 to relate the investment-to-GDP ratio to a broad range of explanatory variables to find the optimal rate of investment. Overinvestment in China was estimated at approximately 10 per cent of GDP. The cost of financing this overinvestment was found to be predominantly borne by households and smallto-medium-sized enterprises through a hidden transfer of resources, estimated at an average of 4 per cent of GDP per year. It was concluded that a 10 percentage point decline in the investment share of the Chinese economy over time would bring investment to levels consistent with fundamentals.

While this estimate is subject to much uncertainty, we proceed to use a 10 percentage point fall in investment as a share of GDP (defined as gross fixed capital formation as a share of GDP) as the basis for the following scenario.

Our analysis also assumes that this decline would take place progressively over the next decade, although we accept that nominating such a precise transition period is somewhat arbitrary. ${ }^{12}$ For reference, our 10-year scenario represents a faster transition than in the 'upside reform scenario' detailed in Nabar and N'Diaye (2013), in which financial sector and resource pricing reforms gradually slow capital accumulation and eliminate excess investment by 2030. In their scenario, the gradual increase in investment from firms in non-manufacturing sectors - lured by prospects of future profits, particularly services - does not fully offset the decline in manufacturing investment, so the share of investment in GDP declines from more than 45 per cent in 2012 to around 35 per cent in 2030 .

Our scenario of a 10 percentage point fall over a 10-year period is broadly consistent with the experiences of other East Asian economies as they developed and returns to capital fell (Figure 5.8). The key difference is that the investment share of the Chinese economy appears to have peaked at an earlier stage of China's development. In Korea, investment peaked at 39 per cent of GDP in 1991 at GDP per capita of \$13 600 (PPP, 2011 prices). By 2001 it had fallen 10 percentage points to 29 per cent. In Japan, investment peaked at 36 per cent of GDP in 1973 at GDP per capita of \$18 300. Over the following 10 years the

12 We begin our transition in 2013 mainly because it is simple, with 2012 the final year for which comprehensive annual data for China are available at the time of writing. 
ratio fell to 28 per cent. ${ }^{13}$ In the case of China, our scenario assumes that the investment share of the economy peaked in 2012 at around 47 per cent, at GDP per capita of $\$ 10200 .^{14}$

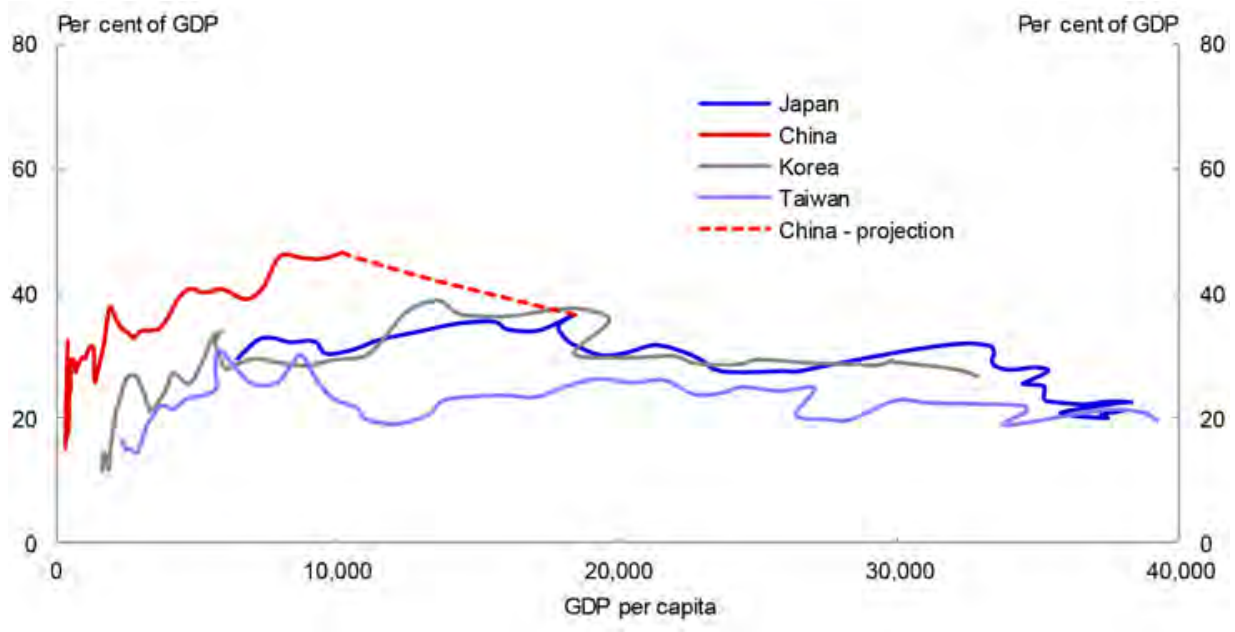

Figure 5.8 Projected Path of Investment-to-GDP Ratio

Sources: World Bank; CEIC Asia; Maddison (2010); and Australian Treasury.

Notes: GDP per capita adjusted for purchasing power parity (2011 prices). Investment defined as gross fixed capital formation.

\section{A greater role for household consumption}

In estimating how a 10 percentage point decline might be transmitted through China's economy, our analysis depends on a number of basic, but defensible, assumptions.

The share of GDP accounted for by government consumption, change in inventories and net exports is assumed to remain constant over the 10-year period. ${ }^{15}$ Government consumption as a share of GDP has been very stable since 1952 (the beginning of the National Bureau of Statistics data set), averaging 13 per cent. This ratio is therefore set at 13.5 per cent over the decade from 2013, which is the average of the 10-year period from 2003. The change in

13 The declining trend in Japan's investment-to-GDP ratio was temporarily disrupted by the late 1980s investment boom, increasing to 32 per cent by 1990. The ratio fell again, however, during the 2000s to reach 25 per cent in 2000 and 21.2 per cent by 2012 .

14 As explained previously, 2012 is the final year for which complete national accounts data were available when this chapter was being prepared.

15 The net exports assumption runs contrary to the conventional wisdom that China's trade surplus would narrow as a result of internal rebalancing. Some of our general equilibrium results below also cast doubt on this conventional wisdom. 
the inventories-to-GDP ratio is set at 2.4 per cent-also the 10-year average from 2003. Net exports-to-GDP has been set at 2.5 per cent, compared with 2.7 per cent in 2012 .

The household consumption share of GDP is then simply calculated as the residual of the sum of government consumption, gross fixed capital formation, change in inventories and net exports. Therefore, a 10 percentage point decrease in the investment-to-GDP ratio over the 10-year projection period results in the household consumption-to-GDP ratio growing from around 35 per cent in 2013 to 45 per cent by 2022 .

This is at the upper end of the shifts towards household consumption in other East Asian economies as their very high rates of investment growth began to ease (Figure 5.9). Notably, this is a little faster than the increases seen in Japan and Korea, where household consumption as a share of GDP rose around 5 percentage points in the decade after peak investment.

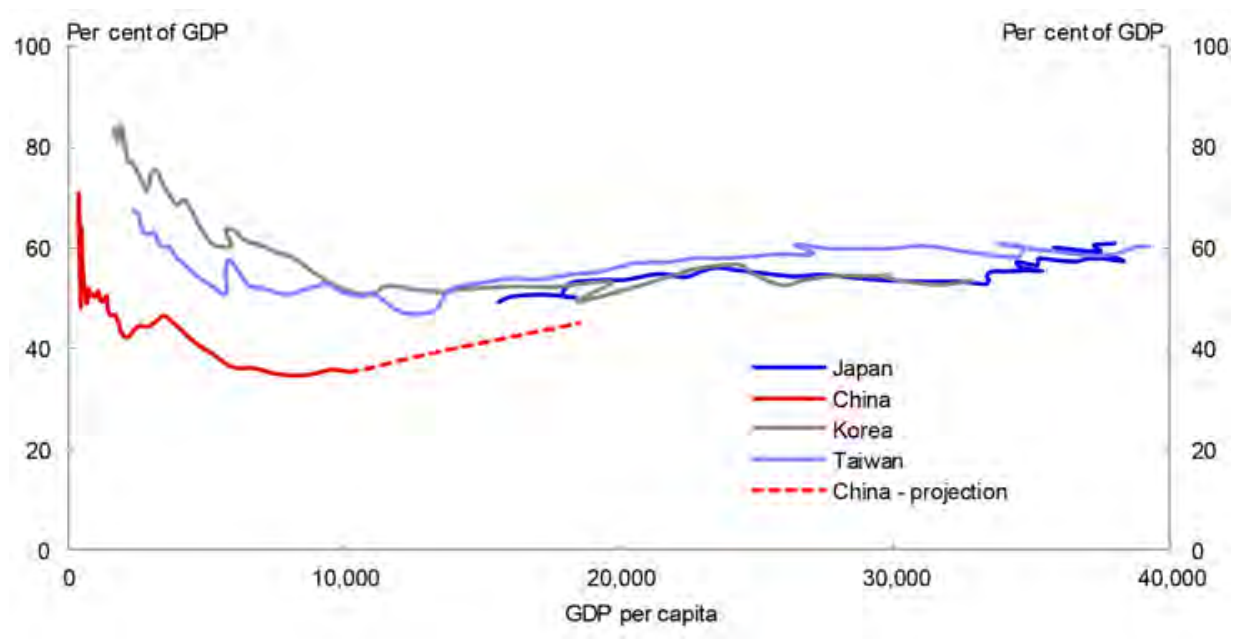

Figure 5.9 Projected Path of Household Consumption-to-GDP Ratio

Sources: World Bank; CEIC Asia; Maddison (2010); and Australian Treasury.

Note: GDP per capita adjusted for purchasing power parity (2011 prices).

In China, as the migration of labour from rural to urban areas runs its course, and as consumers demand more labour-intensive services, household incomes - and with this household consumption - will increase as a share of GDP. This process will be reinforced by market-oriented reforms that gradually reduce the hidden transfer of resources from households to the corporate sector.

Chinese policy is already turning towards measures that will support higher household consumption. These include the staged appreciation of the renminbiwhich will increase Chinese consumers' purchasing power and promote greater 
domestic demand-financial market liberalisation and the development of alternatives to bank deposits with higher returns, hefty increases to minimum wages, and improvements to the social safety net to include items such as basic medical and unemployment insurance.

\section{Implications for growth in GDP and the capital stock}

An examination of the implied nominal growth rates over the 10-year projection period suggests these projected shifts in the shares of investment and household consumption do not have to lead to significant disruptions to economic growth and capital accumulation. ${ }^{16}$ Rather, while this scenario implies a gradual easing in GDP growth rates, it arguably nudges the Chinese economy towards a more sustainable growth path.

This scenario will allow nominal GDP growth to slow from 10 to 8 per cent over the 10-year period. ${ }^{17}$ Relative to average annual growth rates in the 10 year period immediately preceding our projection period, annual growth in household consumption expenditure will slow to 11 per cent, while growth in investment will slow to 5 per cent (Figure 5.10). The share of growth accounted for by household consumption will rise to 57 per cent and investment will decline to 24 per cent (Figure 5.11).

This scenario is also consistent with robust, but slower, growth in China's capital stock over the 10-year projection period. We have increased the 2011 capital stock estimate from Berlemann and Wesselhoft (2012) by our estimates for annual gross fixed capital formation (in US\$ constant 2000 prices). The annual depreciation rate is set at 4.5 per cent over the projection period, broadly consistent with Berlemann and Wesselhofts' estimate for $2011 .^{18}$

16 The nominal GDP (production) result for 2013 has been expanded out to 2018 using implied growth rates from IMF WEO October 2013 projections of nominal GDP levels. From 2019 onwards, nominal GDP projections have been extended by using the Australian Treasury's real GDP growth projections and assuming constant growth of 2.5 per cent in the GDP deflator-down from the IMF's forecast of 2.6 per cent in 2018.

17 While we have focused on nominal GDP growth rates, our basic assumption for growth in the GDP deflator implies a slowing in annual growth of real GDP to around 6 per cent by the end of the projection period.

18 Berlemann and Wesselhoft (2012) applied the same time-varying depreciation rate across all countries in their sample. Between 2000 and 2011, the depreciation rate grew within a range of approximately 4 to 4.5 per cent. This is arguably too low for a rapidly developing economy such as China; however, for consistency purposes we have chosen to use a depreciation rate of 4.5 per cent. 


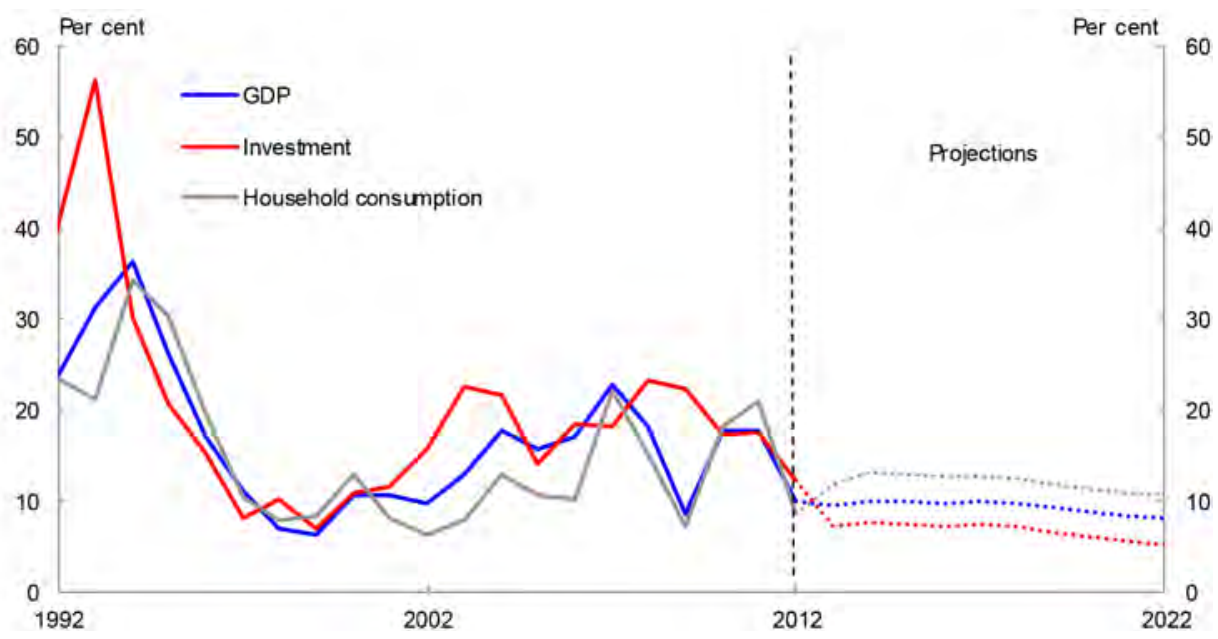

Figure 5.10 Growth in Nominal GDP, Household Consumption and Investment Sources: CEIC China; IMF WEO October 2013; and Australian Treasury.

Notes: GDP (expenditure) breakdown for 2013 not available at time of publishing, hence projections for investment and consumption commence after 2012. GDP growth for 2013 is actual.

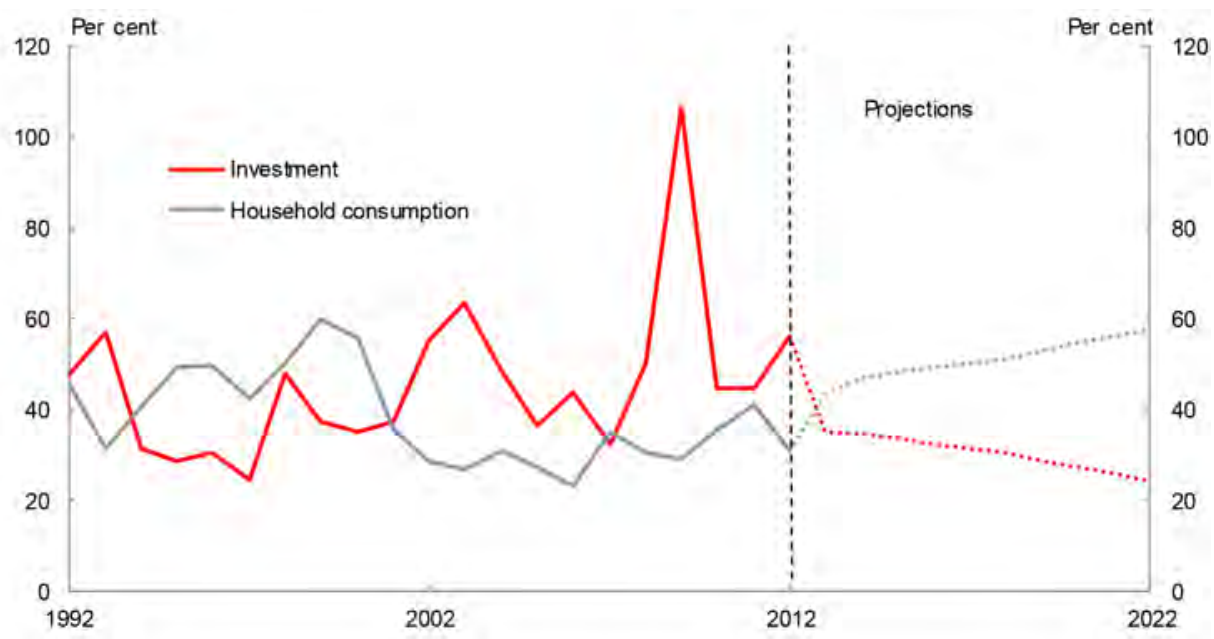

Figure 5.11 Share of Nominal GDP Growth

Sources: CEIC China; IMF WEO October 2013; and Australian Treasury.

Note: GDP (expenditure) breakdown for 2013 not available at time of publishing, hence projections for investment and consumption commence after 2012.

Under this scenario, real annual growth in capital stock will fall to around 7 per cent over the projection period (Figure 5.12). This is consistent with the experience of Korea, according to the results of Berlemann and Wesselhoft (2012). In the 10-year period from 1991, when the investment share of the Korean economy peaked, real annual growth in Korean capital stock fell from 
14 to 6 per cent. China's capital stock per worker (in this case, measured as working-age population) will also continue to increase, although annual growth rates will decline to around 7 per cent over the projection period (Figure 5.13).

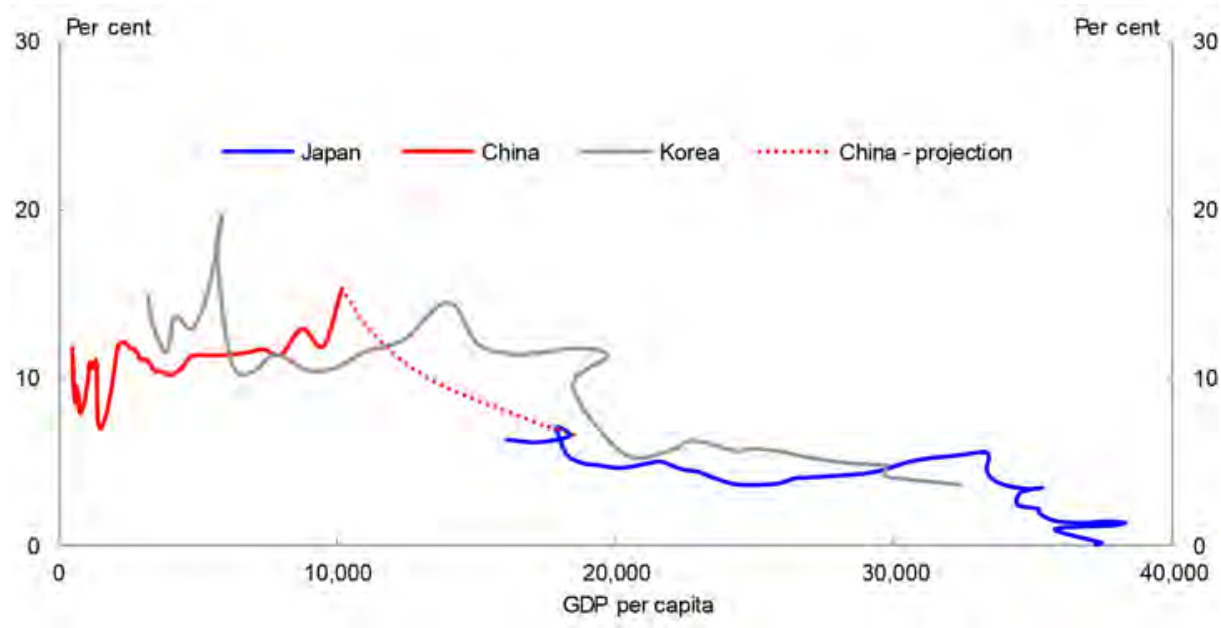

Figure 5.12 Annual Growth in Total Capital Stock

Sources: CEIC China database; IMF WEO October 2013; Berlemann and Wesselhoft (2012); Maddison (2010); and Australian Treasury.

Note: Capital stock is measured in US\$ constant 2000 prices.

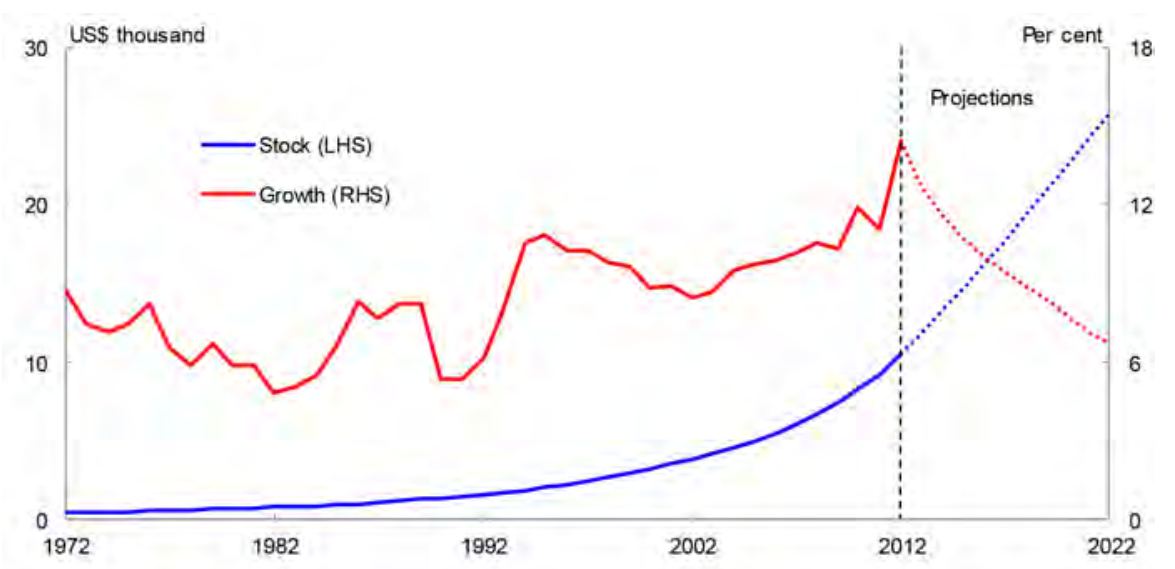

Figure 5.13 Capital Stock Per Worker

Sources: CEIC China database; IMF WEO October 2013; Berlemann and Wesselhoft (2012); and Australian Treasury.

Notes: Capital stock is measured in US\$ constant 2000 prices. Due to data availability, data on working-age population (historical and projections) have been used as proxies for employed workers. 
With China still in the catch-up phase of capital formation, solid growth in China's capital stock will be supported by the urbanisation process. The United Nations estimates that China's urbanisation ratio will reach 61 per cent by 2020 , up almost 10 percentage points from 2012. This means more than 100 million extra urban residents with demands for housing, utility and transport infrastructure, and education and health services. Moreover, higher capital stock per worker will be essential to ensure that ongoing productivity gains go some way to offset the impacts of the decline in China's working-age population.

This suggests the focus on Chinese investment should not be on how excessive it might be, but should address the structural and policy issues in the Chinese economy that negatively affect the allocation and efficiency of investment. Were China to successfully implement the planned market-oriented reforms, private sources of investment could provide a significant offset to reductions in stateled investment, implying that our scenario may understate future growth in China's capital stock per worker.

It is unlikely that actual outcomes would be as smooth as we have assumed. Nonetheless, this analysis indicates that a fall in the investment-to-GDP ratio of 10 percentage points over the next decade need not be overly disruptive to the Chinese economy, in terms of the effects on China's economic growth and rate of capital accumulation. Moreover, this kind of adjustment would not be out of step with the experience of other East Asian economies at similar stages of development, although the sheer size of China's economy and its systemic importance to the global economy - even early in its development - may limit the usefulness of such historical comparisons.

\section{CGE modelling results of a fall in the investment share of GDP}

While our high-level analysis illustrates how a downward adjustment to China's investment share of GDP might take place, a CGE model can shed further light on the channels through which this adjustment would occur, including the impact on China's industry structure and composition of household spending. Given the key purpose of China's planned economic reforms is to improve the economy's productivity, we also explore scenarios in which these reforms boost various productivities and offset the effect on real GDP of lower investment.

To explore these scenarios, we use the version of GTEM mentioned earlier and run a negative 1 percentage point shock on China's investment share of GDP as well as a positive 1 percentage point shock on China's private consumption share of GDP incrementally over a 10-year period, consistent with the above analysis. By the tenth year, the shocks lead to a roughly 10 percentage point reduction in the private saving rate, a 10 percentage point rise in household consumption and a 10 percentage point reduction in investment (all as a percentage of GDP). 
Consistent with our discussion above, the shock on investment could be seen as the result of removing the subsidies for corporate saving and investment, or more broadly, a rise in the cost of investment by the corporate sector. On the other hand, the shock on private consumption could be seen as encompassing wider social reforms that lead to a reduction of the current high rates of precautionary saving by Chinese households.

Compared with the baseline, reducing China's investment share of GDP by 10 percentage points leads to around 2.7 per cent reduction in real GDP, and reduces the size of the capital stock by around 11 per cent.

While the shock represents a significant rebalancing from investment to consumption as a share of GDP, the impact on China's external account is modest. In the absence of productivity improvement from the baseline, China's trade surplus as a share of GDP is around 0.4 percentage points larger because of the shock, while the exchange rate is around 0.5 half a percentage points lower, reflecting a relatively larger reduction in imports than exports.

To better separate the impact of rebalancing on the structure of China's economy from the obvious negative effect on output of lower investment, we implement an offsetting increase in productivity. Again, the kind of offsetting rise in productivity can be viewed as a 'reform dividend' that could accrue to the Chinese economy if the kind of package of reforms announced at the Third Plenum was successfully implemented.

In introducing an offsetting productivity shock, we explore three different channels: input-neutral efficiency; labour efficiency; and capital efficiency. Each of these channels has different effects on the economy, but the last channelvia capital efficiency - arguably lines up best with people's understanding of what China's reform agenda is trying to achieve.

Given China's existing capital stock by industry, there would need to be an approximate 1.6 per cent increase per year in the efficiency of capital to offset the effect of lower investment on real GDP over a 10-year period.

The rebalance from investment to consumption (while holding real GDP constant) leads to a shift in household spending towards services, compared with the baseline (Figure 5.14). Conversely, the shares of household spending on manufactured and rural goods fall. In effect, the boost in consumption reinforces the underlying trend towards services consumption that was already gradually occurring in the baseline in line with growing household incomes.

The rebalance while holding real GDP constant also sees a reduction in China's trade surplus, consistent with the fall in China's saving and the increase in domestic consumption. The shift from investment to consumption also has 
important effects on intermediate demand at the industry level, particularly the capital-producing industries. For example, the intermediate usage by the capital goods sector falls by around 27 per cent for each commodity by the end of the 10-year period.

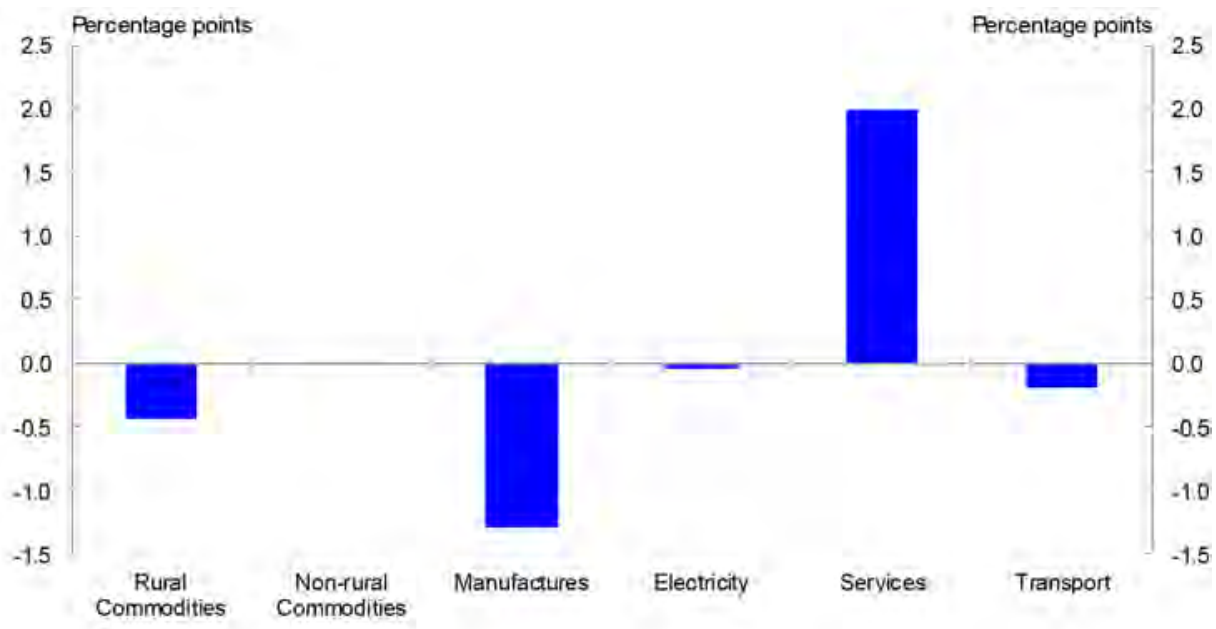

Figure 5.14 Change in Components of Household Consumption (Share of Total) Source: Results from GTEM simulations.

\section{Conclusion}

While there is much debate about the causes and extent of overinvestment in China, we have argued that government policies have indeed contributed to an important degree of excessive investment in recent years. We have also argued that a moderate decline (in the order of 10 percentage points) from the current high rates would not be out of step with the experience of other East Asian economies at similar stages of development, and would be consistent with the market-oriented reforms outlined by the authorities at November 2013's Third Plenum.

While the exact magnitude and timing of any decline in investment rates are highly uncertain, our analysis suggests a 10 percentage point reduction over a 10-year period would be achievable without a destabilising effect on growth and capital accumulation. Moreover, the authorities' reform programif implemented successfully - would probably provide a boost to productivity across the economy over time, helping to offset some of the reduction in real GDP growth that would otherwise result from lower growth in investment. 
Finally, the results from the general equilibrium model suggest the effect of rebalancing from investment to private consumption - even when real GDP is fixed through an offsetting productivity boost - would lead to reduced demand for the output of capital-producing industries and will see consumers shift their spending towards services and away from manufactured goods.

\section{References}

Ahuja, A., Chalk, N., Nabar, M., N'Diaye, P. and Porter, N. (2012), An end to China's imbalances? IMF Working Paper No. 12/100, April.

Aiyar, S., Duval, R., Puy, D., Wu, Y. and Zhang, L. (2013), Growth slowdowns and the middle-income trap, IMF Working Paper No. 13/71, March.

Anand, R., Cheng, K., Rehman, S. and Zhang, L. (2014), Potential growth in emerging Asia, IMF Working Paper No. 14/2, January.

Au-Yeung, W., Kouparitsas, M., Luu, N. and Sharma, D. (2013), Long-term international GDP projections, Australian Treasury Working Paper 2013-02 (January 2014 update).

Aziz, J. and Cui, L. (2007), Explaining China's low consumption: the neglected role of household income, IMF Working Paper No. 07/181, July.

Berlemann, M. and Wesselhoft, J.-E. (2012), Estimating aggregate capital stocks using the perpetual inventory method - new empirical evidence for 103 countries, Working Paper Series No. 125, October, Department of Economics, Helmut Schmidt University, Hamburg.

Cai F., X. Peng and G. Gou (2013), 'The new normal of Chinese development', in R. Garnaut, F. Cai and L. Song (eds), China: A New Model for Growth and Development, pp. 35-54, Canberra: ANU E Press.

Carlyle Group (2013), Recalibrating growth and return expectations in China, June, The Carlyle Group.

Coates, B., Horton, D. and McNamee, L. (2012), 'China: prospects for exportdriven growth', Treasury Economic Roundup (4), Canberra.

Dollar, D. (2013), China's rebalancing: lessons from East Asian economic history, October, Working Paper Series, John L. Thornton China Center. 
Garnaut, R., F. Cai. and Song, L. (2013), 'China's new strategy for long-term growth and development: imperatives and implications', in R. Garnaut, F. Cai and L. Song (eds), China: A New Model for Growth and Development, pp. 1-16, Canberra: ANU E Press.

Hongkong and Shanghai Banking Corporation (HSBC) Global Research (2013), China inside out, return on capital: perception vs reality, April, The Hongkong and Shanghai Banking Corporation Limited.

Hubbard, P., Hurley, S. and Sharma, D. (2012), 'The familiar pattern of Chinese consumption growth', Treasury Economic Roundup (4), Canberra.

International Monetary Fund (IMF) (2012), China: 2012 Article IV Consultation, Staff Report, Country Report No. 12/195, July, International Monetary Fund.

Kong, V., McKissack, A. and Zhang, D. (2012), 'China in a new period of transition', Treasury Economic Roundup (4), Canberra.

Lee, I.-H., Syed, M. and Xueyan, L. (2012), Is China over-investing and does it matter, IMF Working Paper No. 12/277, November.

Lee, I.-H., Syed, M. and Xueyan, L. (2013), China's path to consumer-based growth: reorienting investment and enhancing efficiency, IMF Working Paper No. 13/83, March.

McKay, H. and Song, L. (2013), 'Chinese industrialisation: path dependence and the transition to a new model', in R. Garnaut, F. Cai and L. Song (eds), China: A New Model for Growth and Development, pp. 75-96, Canberra: ANU E Press.

Nabar, M. and N'Diaye, P. (2013), Enhancing China's medium-term growth prospects: the path to a high-income economy, IMF Working Paper No. 13/204, October.

Pant, H. (2007), GTEM: global trade and environment model, ABARE Technical Report, Australian Bureau of Agricultural and Resource Economics. Available from <http://www.daff.gov.au/abares/pages/models.aspx $>$.

Rodrik, D. (2013), The past, present, and future of economic growth, Working Paper 1, June, Global Citizen Foundation.

Szirmai, A. (2008), Explaining success and failure in development, Working Paper Series \#2008-013, February, United Nations University, Unu-Merit.

Tyers, R. (2013), Looking inward for transformative growth in China, Centre for Applied Macroeconomic Analysis Working Paper No. 48/2013, August. 
Tyers, R., Zhang, Y. and Cheong, T.-S. (2013), 'China's saving and global economic performance', in R. Garnaut, F. Cai and L. Song (eds), China: A New Model for Growth and Development, pp. 97-124, Canberra: ANU E Press.

World Bank (2012), China 2030: Building a Modern, Harmonious and Creative High-Income Society, The World Bank and the Development Research Centre of the State Council, People's Republic of China.

Zhang, J. and Zhu, T. (2013), Re-estimating China's underestimated consumption, 7 September 2013. Available from $<$ http://ssrn.com/abstract $=2330698>$. 
This text taken from Deepening reform for China's long-term growth and development, edited by Ligang Song, Ross Garnaut, Cai Fang, published July 2014 by ANU Press, The Australian National University, Canberra, Australia. 